\title{
THE PBRF AND ITS IMPLICATIONS FOR ACADEMICS (IN THE HUMANITIES AND SOCIAL SCIENCES) ${ }^{1}$
}

\author{
Bruce Curtis \\ University of Auckland
}

\begin{abstract}
This paper discusses the likely impacts of the Performance-Based Research Fund, 2003 Quality Exercise on academics in New Zealand. It is argued the Performance-Based Research Fund (PBRF) is one of a number of developments within the 'new managerialism' of public institutions that stands to downgrade forms of professional control enjoyed by academics (Abbott, 1991). The downgrading of academic professions internationally is well-documented (Halsey, 1992) and it would be surprising if academics in New Zealand were exempt from these pressures. More unanticipated, however, is the extent to which academics, at least within the humanities and social sciences of universities, pursue strategies that collectively undercut existing forms of professional control over labour markets, peer review and public esteem.
\end{abstract}

\section{Introduction: Evaluation and the PBRF}

Halsey notes in his influential review of British academics that: "The attack on academic autonomy, or as we have described it the demand from the state that intellectual labour be proletarianized has been conspicuously aggressive in the past decade" (Halsey, 1992: 270).

Evaluations of university research have been introduced by many countries as part of the new management of public institutions, and reflect demands for the sector to be efficient and accountable (Geuna and Martin, 2003; Talib, 2003). The forms of evaluation differ, but there is considerable agreement over their potential to downgrade the forms of control enjoyed by academics as professionals or -perhaps more accurately given the embeddedness of academics in multifaceted institutionsas semi-professionals (Abbott, 1991).

The implementation of the Performance-Based Research Fund (PBRF) can be readily understood as a local example of this new managerialism with the potential to rework academic work and careers in New Zealand.

The stated goal of the PBRF is: "To ensure that excellent research in the tertiary education sector is encouraged and rewarded. This entails assessing the research performance of TEOs [tertiary education organisations] and then funding them on the basis of their performances" (Tertiary Education Commission, 2004a: 3).

The PBRF is managed by the Tertiary Education Commission (TEC) and in 2004 an initial fund of $\$ 18.2$ million was created from $10 \%$ of the research component of the existing EFTS [equivalent full time student] funding to TEOs. In this respect, the PBRF has not increased the pool of funding but makes a percentage of it not follow student enrolments. The research component of EFTS funding will be partly replaced by the PBRF in stages: $10 \%$ in $2004,20 \%$ in $2005,50 \%$ in 2006 and $100 \%$ in 2007 . This will increase the size of the PBRF.
From 2007, the ratio between PBRF and EFTS-based funding will be approximately $20: 80$. That is, the performance-based research fund will account for around one fifth of the funding to TEOs. A second round of the PBRF is scheduled for 2006.

The amount of PBRF funding that each TEO receives is determined by its performance across three components: a Quality Evaluation (QE), in which multidisciplinary panels assess the quality of research of academics who are engaged in teaching and who are employed at the census date for more than a year and at least 0.20 full time equivalents ${ }^{2}$; a measure of research degree completions (RDC); and a measure of external research income (ERI) The ratio of funding for TEOs across the three components QE/ RDC/ ERI is 60:25:15.

\section{Reifying Hierarchies: Institutions and Subjects and Individuals}

The component of the PBRF exercise given the greatest coverage was the 2003 Quality Exercise. The 2003 Quality Exercise made possible comparisons between tertiary education organisations, subjects and individual academics. Much of the material generated by the exercise has been published (Tertiary Education Commission, 2004b) but a wealth of further information is yei to be mined.

The most evident aspect of the Quality Exercise was the ranking of TEOs. This exposed very few surprises. Fortyfive (TEOs) were held eligible by the Tertiary Education Commission to complete the exercise. Twenty-two TEOs participated and 23 opted-out (itself no surprise as these institutions were likely to receive no funding benefits from the exercise). Of the twenty-two that participated there were eight universities (e.g., all the universities), two polytechnics, four colleges of education, one waananga, and seven private training establishments. 
The results were predictable: the seven established universities were all ranked higher than the other TEOs, the newly promoted Auckland University of Technology was ranked $11^{\text {th }}$ (behind 3 bible colleges with a combined academic complement of 28.5 FTE), and the colleges of education were ranked last (Tertiary Education Commission, 2004a: 4-11).

Table 1: University Ranking:

\begin{tabular}{|c|l|c|}
\hline Ranking & \multicolumn{1}{|c|}{ Name } & FTE-weighted quality scores \\
\hline 1 & University of Auckland & 3.96 \\
\hline 2 & University of Canterbury & 3.83 \\
\hline 3 & Victoria University of Wellington & 3.39 \\
\hline 4 & University of Otago & 3.23 \\
\hline 5 & University of Waikato & 2.98 \\
\hline 6 & Lincoln University & 2.56 \\
\hline 7 & Massey University & 2.11 \\
\hline 11 & Auckland University of Technology & 0.77 \\
\hline
\end{tabular}

(Tertiary Education Commission, 2004a: 11)

With hindsight, perhaps the University of Canterbury did a little better than expected and the University of Otago a little worse. Regardless, the ratings confirmed what was generally understood to be the academic pecking order: first Auckland, as part of a cohort made up of the 4 main colleges of the former University of New Zealand; then Waikato (established 1964) and the former agricultural colleges (Massey and Lincoln); last -and still looking like a polytechnic- the recently promoted Auckland University of Technology (established 2000).

As noted, just over half of the PBRF-eligible TEOs constituting a majority of polytechnics, waananga and private training establishments opted out of the exercise, while all of the universities participated. This reflects the reifying aspect of the 2003 Quality Exercise and the vested interests in the process. Insofar as the performance-based research fund reallocates funding to TEOs with the highest ratings, this is likely to reinforce existing divisions in resourcing. Indeed, a reallocation towards the universities and away from other TEOs was undoubtedly the main reason why the New Zealand Vice Chancellors Committee (NZVCC) played a leading role in developing and implementing the 2003 Quality Exercise (see Barnes, 2004).

Similarly, the potential to reallocate resources towards universities (and away from other tertiary education organisations) accounts for the tentative support of the union, the Association of University Staff (AUS), which has coverage over academic and general staff in the universities (with the significant exclusion of Auckland University of Technology). ${ }^{3}$ Thus, critical support by AUS for the PBRF was based on the following considerations:

* The PBRF assessment should clearly distinguish the performance of universities as research-led institutions, and distribute funding accordingly;

* It should also address the long-standing anomaly of the EFTS-funding system whereby all providers receive the same funding per student, with no recognition of the extra research obligations of universities" (Association of University Staff, 2002).

Yet there are significant issues around resource allocation within the university sector. Thus, the University of Canterbury and Auckland University of Technology are roughly comparable in terms of academic complement and student numbers, but the funding mechanisms introduced by the PBRF will significantly advantage the former over the latter. In 2004 alone, the PBRF will deliver $2.15 \%$ more funding to the University of Canterbury and $4.47 \%$ less to Auckland University of Technology (Tertiary Education Commission, 2004a: 80). This difference will increase as the PBRF delivers a larger share of funding, until 2007 when the scheme will be fully implemented. In 2004 the PBRF only delivered a $10 \%$ 'top-up' to funding.

In this respect, the PBRF is likely to reify the existing hierarchy of universities and other TEOs. This differentiation is an intended consequence: "The PBRF rewards research activities of national and international excellence. It therefore introduces a powerful new incentive for TEOs to concentrate their research around areas of excellence. They are encouraged to aim for depth rather than breadth in their research capacity" (Tertiary Education Commission, 2004a: 1).

However, from the perspective of academic professional control the differences likely to be reinforced at the institutional (TEO) level by the PBRF are of a second order. Any hierarchy of universities per se does not constitute a threat to academic control. Indeed, it is possible the opposite is the case: academic careers typically involve promotions associated with movements between more and less prestigious universities. Of greater concern to academics as a profession is the extent to which the institutional differentiation reinforced by the PBRF reduces the total options available to them. Academic labour markets are typically constituted as core and periphery (Connell and Wood, 2002). In this respect, a widening gap between the 'core' (Auckland, Canterbury, Otago, Victoria) and the 'periphery' (the rest of the universities) is of little concern. Academics should 
be less sanguine however where the process of differentiation reduces the overall pay and conditions in the sector and where specific (low rated, under resourced) universities enforce disadvantageous arrangements.

The separation of teaching and research is a significant concern for academics insofar as it reduces the overall pay and conditions of the sector. Auckland University of Technology has introduced elements of this division in the wake of the PBRF (although research track academics still undertake more teaching than the counterparts in the longer established universities). Worryingly, the separation of teaching and research is only a viable response to the PBRF insofar as it involves the casualization of this teaching (as senior tutors on permanent contracts were assessed in the 2003 Quality Evaluation). The move to fixed term contracts in teaching and in research has been a main feature of academic work and careers in Britain following the RAE (Collinson, 2002) and seems likely to be used here both for reasons of cost efficiencies and for institutional gaming in response to future Quality Evaluations. That is, senior tutors on fixed term contracts of less than 12 months would not be assessed under the current PBRF methodology.

The 2003 Quality Evaluation also generated considerable material on the subjects that comprise academia. The Tertiary Education Commission constituted twelve expert panels to assess the quality of research of individual academics across forty one 'subject areas'. The twelve multidisciplinary panels typically involved around 20 academics comprised from the professoriate and including at least one senior academic employed outside New Zealand and one expert in Maori knowledge. The main task of these panels was to evaluate the Evidence Portfolios of individual academics and to assign a numeric and letter grade (R, less than 200; C 200-399; B, 400-599, A 600-700). ${ }^{4}$

Three panels covered the range of subjects associated with the Arts: Social Sciences \& Other Cultural/Social Studies ( 6 subjects), Humanities and Law ( 6 subjects) and Education (1 subject) (see, Tertiary Education Commission, 2004b: 18):

Table 2: Social Sciences \& Other Cultural/Social Studies; Humanities and Law; Education Panels

\begin{tabular}{|c|c|c|c|c|c|}
\hline Subject & Quality Score & FTE Staff & $\begin{array}{l}\text { Representation } \\
\text { on Panel }\end{array}$ & $\begin{array}{l}\text { Representation / } \\
\text { FTE Staff }\end{array}$ & Descriptor \\
\hline Philosophy & $4.74(1)$ & $64.2(9)$ & $I(10)$ & $64.2(11)$ & $1(1)$ \\
\hline Anthropology \& Archaeology & $4.55(2)$ & $59.2(10)$ & $2(7)$ & $29.6(2)$ & $2(4)$ \\
\hline Psychology & $3.97(3)$ & $217.5(3)$ & $5(2)$ & $43.5(4)$ & $1(1)$ \\
\hline Human Geography & $3.96(4)$ & $58.2(11)$ & $\mathrm{I}(10)$ & $58.2(9)$ & $2(4))$ \\
\hline $\begin{array}{l}\text { History, History of Art, Classics \& } \\
\text { Curatorial Studies }\end{array}$ & $3.75(5)$ & $188.3(5)$ & $8(1)$ & $23.5(1)$ & $6(10)$ \\
\hline $\begin{array}{l}\text { Political Science, International } \\
\text { Relations \& Public Policy }\end{array}$ & $3.40(6)$ & $94.1(8)$ & $2(7)$ & $47.5(5)$ & $6(10)$ \\
\hline Law & $2.97(7)$ & $221.7(2)$ & $4(3)$ & $55.4(8)$ & $1(1)$ \\
\hline English Language \& Literature & $2.75(8)$ & $117.9(6)$ & $2(7)$ & $58.9(10)$ & $3(6)$ \\
\hline Foreign Language and Linguistics & $2.46(9)$ & $202.2(4)$ & $4(3)$ & $50.5(6)$ & $3(6)$ \\
\hline Religious Studies and Theology & $2.46(9)$ & $51.3(12)$ & $\mathrm{I}(10)$ & $51.3(7)$ & $3(6)$ \\
\hline $\begin{array}{l}\text { Sociology, Social Policy, Social Work, } \\
\text { Criminology and Gender Studies }\end{array}$ & $2.40(11)$ & $233.3(1)$ & $3(5)$ & $77.7(12)$ & $8(12)$ \\
\hline $\begin{array}{l}\text { Communications, Journalism and } \\
\text { Media Studies }\end{array}$ & $1.59(12)$ & $97.5(7)$ & $3(5)$ & $32.5(3)$ & $4(9)$ \\
\hline Education & 1.02 & 994.8 & & & 1 \\
\hline
\end{tabular}

The ranking of subjects also largely confirmed the commonly accepted hierarchy: "In general, the best results were achieved by long-established disciples with strong research cultures..." (Tertiary Education Commission, 2004b: 9). However, the assessment of subjects was made more contentious because of the decisions in grouping / creating subject areas. Thus (in the Arts at least), the extent to which a discipline stood alone in a 'subject area' was the best external predictor of its Quality Score. For example, Philosophy and Psychology were obvious beneficiaries in this delineation, while the subject area of Human Geography also benefited from its separation from the general field of geography.

More significantly, the grouping of disciplines into subject areas, the constitution of multidisciplinary panels and the methodology of assessing Evidence Portfolios points to the relatively slight influence of academics as disciplinary practitioners in the development of the PBRF. While the 2003 Quality Evaluation provides considerable information for policymakers and a 
powerful resource for senior management of universities, the benefits to disciplines and to disciplinary associations is by no means clear. While the planning offices of individual universities are no doubt engaged in the analysis of the PBRF finding and strategising accordingly, the role of individual academics and their associations is problematic.

Clearly, the PBRF must have a institutional focus and should measure the extent to which the obligations laid out by the Education Act (1989), section 254(3)(a) that degrees must be 'taught mainly by people engaged in research' are being met. However, the extent to which the institutions and the senior managers of institutions are favoured by this exercise vis $a$ vis academics and their disciplinary associations is extreme. This imbalance is exemplified in the decision made by TEC in consultation with the NZVCC to determine quality categories for individual academics. Professor Jonathan Boston, the principal architect of the PBRF methodology has provided a rationale for this decision (Boston, 2004). The benefits of individual ratings included: it would reduce compliance costs, it was congruent with research practice, it enhanced self-assessment, it was consistent with multidisciplinary panels, it provided more powerful incentives, it was more honest and transparent (Curtis, author's notes from the plenary session, 21-5- 2004). Boston (2004) has also indicated that decision to individual ratings did not provide these benefits. Indeed. it is difficult to find any public support for individual ratings. In this regard, the Phase I Evaluation of the implementation of the PBRF and the conduct of the 2003 Quality Evaluation rather wanly recommends: "That the individual staff member be retained as the unit of assessment in the Quality Evaluation". (Web Research, 2004: 13)

Individual ratings may not provide the benefits hoped for by Professor Boston, but they do deliver a powerful resource to the senior managers of universities and to human resource practitioners. Extensive interviewing has suggested that the potential for the Quality Evaluation to provide a rating of individual staff proved an irresistible opportunity for the most senior management of universities operating as the NZVCC. The consequences of the resultant bundling of an HR component with the assessment of research are not yet worked through, but seem likely to be to the detriment of academic professional control.

\section{Meeting the 'HR Challenge'}

The methodology for assessing the research performance of TEOs and individual academics is complex and ramifications of the results will take time to work through (see, Tertiary Education Commission, 2004b for an extensive discussion of the methodology and results). Nevertheless, Professor Pat Walsh, leading industrial relations expert and Pro VC (Commerce and Research), Victoria University of Wellington notes the PBRF strengthens and justifies the activities of human relations practitioners (HR) in universities:
"Now under the previous funding system universities could afford - they might not have liked it - but they could afford to take a tolerant view of those whose research performance was inadequate. Under the PBRF this will become more difficult. The fundamental - and I'm attempted to say unique - aspect of the PBRF is the one-to-one relationship it establishes between the research performance of individual academic staff and the reputation and revenue of the institution. Our principal funder has decided that our revenue will rise and fall directly with the assessed research performance of each academic... The challenge for universities under the current PBRF regime will be establish performance management systems which fairly assess the contribution made by academic staff, including those whose research performance is demonstrably unsatisfactory. ... This means that all universities face the fundamental HR challenge of developing performance management systems which properly recognise both the collective nature of research production and the variable nature of individual contribution to the collective effort" (Walsh, 2004).

The less 'tolerant' HR and its move into the realms of academic endeavour is likely to be uneven across universities but has powerful drivers in the PBRF. There are at least four critical ratios in the methodology of the PBRF around which individual universities (and other TEOs) will strategise and which constitute the 'HR challenge'.

It must be acknowledged that 20:80 ratio between PBRF and EFTS means that while the emphasis on maximising student numbers will abate it will remain central. However, high ratings under the PBRF also bring reputational benefits and possible multiplier effects for the top-ranked universities. It seems to be assumed by senior management in universities that EFTS will also follow PBRF success. This assumption explains the (successful) effort on the part of the New Zealand Vice Chancellor's Committee (NZVCC) to ban publication of the part of the PBRF report (e.g., Tertiary Education Commission, 2004b) that made comparison between New Zealand and foreign universities. It might also be argued, that the NZVCC considered that the performance of its members should be exempt from the kind of comparisons made on academic staff in the 2003 Quality Evaluation.

Certainly, the resources made available through the PBRF -at least formally disconnected from EFTS- provides opportunities for senior management in universities to strategise, in effect to pick winners. In this respect, it is significant that while staff participation in the 2003 Quality Evaluation was mandated by line management in universities, no agreements were secured by staff at any university as to how any windfall from the PBRF might be spent. Other key ratios in the PBRF methodology provide insights into the strategies and gaming that senior management / HR are likely to prefer.

As noted, the ratio for the components of PBRF funding is 60:25:15 between Quality Evaluation/ research degree completion/ external research income. This means that the greatest proportion of funding comes from the 
assessment of the quality of research of individual academics. Arguably the greatest gains can come from improving quality scores of institutions and their nominated output units, although it should be noted that research degree completions (i.e., of $\mathrm{PhDs}$ ) is regarded as a relatively soft option and is likely to attract resourcing.

In the realm of quality scores the key ratio is the rating of staff in terms of $A / B / C / R$ quality scores with the calculation of funding. This is 10:6:2:0. Thus, a B academic is worth three times as much as his $\mathrm{C}$ counterpart; an A academic is worth five of her C colleagues; and, a R academic is worth nothing at all. The HR drive is clear: to maximise A's, to identify and raise high B's and C's, to minimise R's. How this is worked through on an institutional basis is unclear. One Vice Chancellor has proposed and subsequently retracted the payment of bonuses to $\mathrm{A}$ and $\mathrm{B}$ rated staff. The most immediate and likely result is in the area of staff hiring, where senior management and HoDs are extremely reluctant to hire junior staff who may accrue $R$ 's (the next census date is 21-12-2005). This is also the realm of unintended consequences insofar as disciplines and institutions that have experienced growth in recent years are likely to have more junior staff and subsequently R's and C's than those were stable or in decline. Possibly the good result of the University of Canterbury vis $a$ vis the University of Otago reflects this pattern.

Not all subject areas are treated equally by the PBRF. All of the subject areas assessed by the Social Sciences \& Other Cultural/Social Studies; Humanities and Law; Education Panels were assigned a weighting of 1 with the exception of Psychology (with a weighting of 2). Similarly the subject areas in the creative and Performing Arts Panels were assigned a weighting of 2 . This has obvious consequences at the margins for the constitution of academic departments and units (albeit at the margins) insofar as a social psychologist assessed as a sociologist is worth half the value of one assessed as a psychologist, etc. The overall effect on the Arts in comparison with other Faculties is likely to be negative. The Minister of Finance argued recently that:

"The Recent analysis for the Performance-Based Research Fund showed that New Zealand academics are world-class in areas such as philosophy and criminology; but we need to ensure that we are world class in biotechnology and the other disciplines that, in the medium to long-term, will pay the bills. It is time to shif the balance of our tertiary system towards more of an explicit industry-led approach." (Cullen, 2004)
At the same time, Professor Walsh is undoubtedly correct in his estimation of a new challenge for HR. The PBRF has provided both resourcing and a rationale for a greater involvement of HR practitioners and managerialism in general in research (and teaching). These initiatives are likely to challenge the ideals of professional control by academics.

\section{Euphoria or Despondency}

Recent survey of staff by the AUS (Chalmers, 1998; Scott and Scott, 2004) and myself (see appendix 1) indicate that academic staff consider themselves overworked and stressed. The AUS sponsored study 'Workload and Stress in New Zealand Universities' reported that in 1998 academics worked on average a 53 hour week (Chalmers, 1998: 18). This reflected that growth / massification of university enrolments. The ratio of EFTS/FTE academics rose from 12.5 in 1980 to 18.0 in 1991 and has remained constant since Scott and Scott (2004: 2).

The mix of work experienced by was far from ideal. In 1998 academics spent on average:

\footnotetext{
* $48 \%$ of their time on teaching ( $48 \%$ in 1994$)$

$* 21 \%$ on research $(23 \%$ in 1994$)$

* $20 \%$ on internal administration and meetings $(21 \%$ in 1994), and

* $12 \%$ on other areas $(8 \%$ in 1994) (Chalmers, 1998: 25).
}

Further, the 3 top-ranking changes which would make academics work more worthwhile were:

* more time to spend on research or publishing (44\%)

* decreased workload

* salary increase (23\%) (Chalmers, 1998: 50).

These results are confirmed by my own survey in which academics reiterate the worth of their endeavours and uncertainty about the benefits of the PBRF / managerialism. The first phase of this research involved a mail-out survey to all academic staff at the eight New Zealand universities, located in the humanities and social sciences. In late 2003, 1779 questionnaires were sent out. 617 completed questionnaires were returned, along with 44 uncompleted ones. Among other things, the questionnaire asked academics to rate 56 statements in terms of a Likert scale (Strongly Agree $=5$, Agree $=4$, Neutral $=3$, Disagree $=2$, Strongly Disagree $=1$ ) . 
Academics rated a question about the benefits of the PBRF only middling:

33 The Performance Based Research Funding initiative is beneficial

Academics were much clearer that academic positions should combine teaching and research:

\begin{tabular}{|l|l|l|}
\hline 1 & Academic positions should combine teaching and research & 4.49 \\
\hline 43 & The main function of the tertiary sector should be teaching & 2.56 \\
\hline 44 & The main function of the tertiary sector should be research & 2.56 \\
\hline 49 & There should be greater use of contract teaching & 2.27 \\
\hline 51 & Most academics should focus exclusively on teaching & 1.86 \\
\hline 52 & Most academics should focus exclusively on research & 1.85 \\
\hline
\end{tabular}

And, were confident about the comparative quality of the NZ sector:

\begin{tabular}{|l|l|l|}
\hline 5 & NZ academics have much to contribute internationally & 4.20 \\
\hline 20 & New Zealand delivers world-class tertiary education & 3.37 \\
\hline 21 & The esteem in which NZ research is held internationally has increased & 3.28 \\
\hline 53 & Research and ieaching in NZ is usually just reinventing the wheel & 1.84 \\
\hline 56 & NZ academics have little to contribute internationally & 1.58 \\
\hline
\end{tabular}

They were somewhat pessimistic about the tertiary sector:

\begin{tabular}{|l|l|l|}
\hline 17 & Collegiality is in decline & 3.49 \\
\hline 25 & I am pessimistic about the future of the tertiary sector & 3.23 \\
\hline 36 & I am optimistic about the future of the tertiary sector & 2.72 \\
\hline 39 & Now is a good time to be an academic & 2.65 \\
\hline
\end{tabular}

But, were more optimistic about their own careers:

\begin{tabular}{|l|l|l|}
\hline 27 & I am optimistic about my career & 3.15 \\
\hline 38 & I am pessimistic about my career & 2.69 \\
\hline
\end{tabular}

Most significantly academics supported the 'traditional' conditions of academic work and career:

\begin{tabular}{|l|l|l|}
\hline 1 & Academic positions should combine teaching and research & 4.49 \\
\hline 2 & Sabbaticals are important for good teaching and research & 4.45 \\
\hline 4 & $\begin{array}{l}\text { The funding of conference attendance is crucial for good teaching and } \\
\text { research }\end{array}$ & 4.29 \\
\hline 6 & Administrative work has become an unreasonable burden & 4.12 \\
\hline 46 & $\begin{array}{l}\text { The tertiary sector should focus on meeting the demands of the knowledge } \\
\text { economy }\end{array}$ & 2.35 \\
\hline 49 & There should be greater use of contract teaching & 2.27 \\
\hline 50 & There should be a greater focus on wealth generating aspects of research & 1.86 \\
\hline 54 & The tertiary sector should be run like a business & 1.70 \\
\hline
\end{tabular}


However, subsequent interviews with academics and analysis of the qualitative survey data suggests a distinctly binomial response to the PBRF, in the form of euphoria or despondency. Academics seem split between overwhelming relief or abject misery about the outcome of the 2003 Quality Evaluation. Neither response is particularly promising in terms of reaffirming professional control. Both are suggestive of a disengagement with the PBRF process and, in particular, with the detail of the methodology used. At the same time, both (extreme) positions imply an alignment of effort with the indicators fabricated from 'on high' rather than a thorough interrogation of the worth and validity of those indicators.

\section{References}

Association of University Staff, (2002). PerformanceBased Research Fund: Policy statement, http://www.aus.ac.nz/policy_professional/PBRF/p olicy.htm, accessed 1 October 2004.

Abbott, A. (1998). Professionalism and the future of librarianship, Library Trends, 46(3): 430-443.

Barnes, T. (2004). Transcript of Plenary Sessions, PBRF Forum: Evaluation the Assessment Framework, The Royal Society of New Zealand Social Sciences Committee, http://www.rsnz.govt.nz/ advisory/social_science/media/pbrf2004plenary.php, accessed 1 October 2004.

Boston, J. (2004). Transcript of Plenary Sessions, PBRF Forum: Evaluation the Assessment Framework, The Royal Society of New Zealand Social Sciences Committee, http://www.rsnz.govt.nz/ advisory/social_science/media/pbrf2004plenary.php, accessed 1 October 2004

Chalmers, A. (1998). Workload and stress in New Zealand universities in 1998: A follow-up to the 1994 study, Wellington: New Zealand Council for Educational Research and The Association of University Staff of New Zealand.

Collinson, J.A. (2002). Occupational identity on the edge: Social science researchers in higher education, Sociology, 32(2): 313-329.

Connell, R,W and J. Wood, (2002). Globalization and scientific labour: Patterns in a life-history study of intellectual workers in the periphery, Journal of Sociology, 38(2): 167-190.
Cullen, M. (2004). Speech to Hamilton Club ABN AMRO Craigs Economic Breakfast Briefing: NZ's Path to Growth, Hamilton Club, Hamilton, 15 July 2004 .

Dalziel, P. (2004). Transcript of Plenary Sessions, PBRF Forum: Evaluation the Assessment Framework, The Royal Society of New Zealand Social Sciences Committee, http://www.rsnz.govt.nz/ advisory/social_science/media/pbrf2004plenary.php, accessed 1 October 2004.

Guena, A. and B.R. Martin, (2003). University research evaluation and funding: An international comparison, Minerva, 41: 277-304.

Halsey, A.H. (1992) Decline of donnish dominion : the British academic professions in the twentieth century, New York : Oxford University Press.

Scott, W.A. and H.M. Scott, (2004). University income and student numbers between 1980 and 2002: Summary tables and charts, http://www.aus.ac.nz/funding/tables.pdf, accessed 1 October 2004.

Talib, A.A. (2003). The offspring of new public management in English universities: 'Accountability', 'performance measurement', 'goal-setting' and the prodigal child -the RAE, Public Management Review, 5(4): 573-583.

Tertiary Education Commission, (2004a). Overview and key findings: Performance-based research fund, evaluating excellence: the 2003 assessment, Wellington: Tertiary Education Commission.

Tertiary Education Commission, (2004b). Performance-based research fund, evaluating excellence: the 2003 assessment, Wellington: Tertiary Education Commission.

Walsh, P. (2004). Transcript of Plenary Sessions, PBRF Forum: Evaluation the Assessment Framework, The Royal Society of New Zealand Social Sciences Committee, http://www.rsnz.govt.nz/ advisory/social_science/media/pbrf2004-plenary. php, accessed 1 October 2004.

Web Research, (2004). Phase I Evaluation of the implementation of the PBRF and the conduct of the 2003 Quality Evaluation, Wellington: Centre for Research on Work, Education and Business Ltd. 


\section{Appendix 1: Rating statements}

The table below shows statements ranked in descending order of agreement.

\begin{tabular}{|c|c|c|c|}
\hline & $\mathbf{N}$ & Mean & SD \\
\hline Academic positions should combine teaching and research & 610 & 4.49 & .681 \\
\hline Sabbaticals are important for good teaching and research & 611 & 4.45 & .742 \\
\hline Academics deserve better pay and conditions & 609 & 4.30 & .827 \\
\hline $\begin{array}{l}\text { The funding of conference attendance is crucial for good teaching } \\
\text { and research }\end{array}$ & 609 & 4.29 & .823 \\
\hline $\mathrm{NZ}$ academics have much to contribute internationally & 608 & 4.20 & .676 \\
\hline Administrative work has become an unreasonable burden & 610 & 4.12 & .870 \\
\hline Students should be asked to rate the effectiveness of teaching & 603 & 4.06 & .864 \\
\hline Teaching is under valued & 610 & 4.05 & .978 \\
\hline Tenure is crucial for good teaching and research & 605 & 3.79 & 1.040 \\
\hline Greater inter-disciplinarity is a positive development & 610 & 3.78 & .769 \\
\hline The number of students I teach and supervise has increased & 592 & 3.77 & 1.107 \\
\hline There should be greater inter-disciplinarity & 600 & 3.73 & .920 \\
\hline There should be a greater appreciation of multiculturalism & 604 & 3.67 & .898 \\
\hline Academics are highly productive & 597 & 3.60 & .775 \\
\hline Secondary students are poorly prepared for the tertiary sector & 608 & 3.59 & .980 \\
\hline Socio-economic disadvantage is the most important equity issue & 604 & 3.51 & .952 \\
\hline Collegiality is in decline & 609 & 3.49 & 1.040 \\
\hline Tertiary education should be free & 606 & 3.45 & 1.197 \\
\hline Academic freedom is under attack & 609 & 3.40 & .980 \\
\hline New Zealand delivers world-class tertiary education & 606 & 3.37 & .943 \\
\hline $\begin{array}{l}\text { The esteem in which NZ research is held internationally has } \\
\text { increased }\end{array}$ & 593 & 3.28 & 679 \\
\hline Inter-disciplinarity is an increasing feature of the tertiary sector & 607 & 3.27 & .881 \\
\hline $\begin{array}{l}\text { Rulings requiring minimum class sizes stifle creativity and } \\
\text { innovation in teaching }\end{array}$ & 602 & 3.27 & 1.060 \\
\hline There should be a greater emphasis on traditional scholarship & 578 & 3.27 & .978 \\
\hline I am pessimistic about the future of the tertiary sector & 608 & 3.23 & 1.022 \\
\hline Academics are ably represented by their union & 602 & 3.19 & 1.001 \\
\hline I am optimistic about my career & 602 & 3.15 & 1.116 \\
\hline My research endeavours are well supported & 607 & 3.08 & 1.078 \\
\hline My institution fosters my career development & 604 & 3.06 & 1.069 \\
\hline $\begin{array}{l}\text { Attracting full fee paying students is vital for the future of the } \\
\text { tertiary sector }\end{array}$ & 603 & 3.04 & 1.004 \\
\hline Research is under valued & 609 & 3.00 & 1.095 \\
\hline $\begin{array}{l}\text { The integration of Treaty issues into the curriculum should be } \\
\text { given priority }\end{array}$ & 610 & 2.93 & 1.122 \\
\hline The Performance Based Research Funding initiative is beneficial & 593 & 2.90 & 1.127 \\
\hline It is very difficult to publish $\mathrm{NZ}$ research internationally & 604 & 2.83 & .989 \\
\hline $\begin{array}{l}\text { Student feedback and surveys on effective teaching are just } \\
\text { popularity polls }\end{array}$ & 607 & 2.76 & 1.067 \\
\hline I am optimistic about the future of the tertiary sector & 607 & 2.72 & 1.032 \\
\hline $\begin{array}{l}\text { The integration of Treaty issues into the curriculum should be } \\
\text { downplayed }\end{array}$ & 609 & 2.69 & 1.196 \\
\hline I am pessimistic about my career & 601 & 2.69 & 1.196 \\
\hline Now is a good time to be an academic & 610 & 2.65 & 1.002 \\
\hline Equity initiatives come at the expense of quality & 605 & 2.62 & 1.085 \\
\hline
\end{tabular}




\begin{tabular}{|l|c|c|c|}
\hline There should be minimum class sizes at the postgraduate level & 607 & 2.58 & 1.152 \\
\hline New Zealanders should have preference in gaining academic jobs & 608 & 2.58 & 1.119 \\
\hline The main function of the tertiary sector should be teaching & 608 & 2.56 & 1.031 \\
\hline The main function of the tertiary sector should be research & 603 & 2.56 & .992 \\
\hline $\begin{array}{l}\text { The funding and other support of teaching and research is } \\
\text { improving }\end{array}$ & 602 & 2.49 & .962 \\
\hline $\begin{array}{l}\text { The tertiary sector should focus on meeting the demands of the } \\
\text { knowledge economy }\end{array}$ & 602 & 2.35 & 1.018 \\
\hline Women should have preference in gaining academic jobs & 604 & 2.33 & .867 \\
\hline Maori should have preference in gaining academic jobs & 602 & 2.32 & 1.008 \\
\hline There should be greater use of contract teaching & 605 & 2.27 & 1.044 \\
\hline $\begin{array}{l}\text { There should be a greater focus on wealth generating aspects of } \\
\text { research }\end{array}$ & 609 & 1.86 & .858 \\
\hline Most academics should focus exclusively on teaching & 606 & 1.86 & .708 \\
\hline Most academics should focus exclusively on research & 610 & 1.85 & .720 \\
\hline Research and teaching in NZ is usually just reinventing the wheel & 605 & 1.84 & .780 \\
\hline The tertiary sector should be run like a business & 607 & 1.70 & .903 \\
\hline Academics are an overpaid profession & 610 & 1.60 & .732 \\
\hline NZ academics have little to contribute internationally & 608 & 1.58 & .885 \\
\hline
\end{tabular}

\section{Notes}

' This research is part funded by the University of Auckland Research Fund. The focus of the research is to assess how academic staff feel about and are responding to developments in the tertiary education sector. The first phase of the research involved a mail-out survey to all academic staff in at the eight New Zealand universities located in the humanities and social sciences. In late 2003, 1779 questionnaires were sent out. 617 completed questionnaires were returned, along with 44 uncompleted ones. The questionnaire asked academics: (1) to rate 56 statements in terms of a Likert scale; (2) to answer opened-ended questions about the most worrying and encouraging developments for the tertiary sector; and (3) to provide some biographical material (age, gender, ethnicity) and a career profile (years in job, institution, academic rank, discipline, degree). The second phase of the research is ongoing and involves analysis of survey data, interviews with academics, university management, union representatives and staff of various ministries and sector organisations.

${ }^{2}$ While the goal of the PBRF is research focused, its origins in EFTS-based funding of teaching created at least one major inconsistency: staff employed on 'research only' contracts were not assessed in the 2003 Quality Evaluation while many (mainly senior tutors) on 'teaching only' contracts were. A number of respondents have argued that the inclusion of teaching in the assessment of research was necessary in order to prevent the non-university TEOs from 'gaming'. That is, the universities would be less adversely affected by the inclusion of teaching only staff that the polytechnics, colleges of education, waananga, and private training establishments.

${ }^{3}$ Staff at Auckland University of Technology are covered by the ATSE. The ATSE also covers staff at the polytechnics.

${ }^{4}$ Professor Paul Dalziel (2004), has noted that the sections on contribution to research environment and peer esteem were more likely to reduce the quality score of potential A academics. 